\title{
The Mechanism of Interaction of Virtual Companies with the Companies of Various Forms Manufacturing Technically Sophisticated Products
}

\author{
Kazmina I.V.* \\ Military educational scientific center \\ Air force Academy named after professor N. E. Zhukovsky \\ and Y. A. Gagarin \\ Voronezh, Russia \\ e-mail: kazminakazmina@yandex.ru
}

\author{
Schegoleva T.V. \\ Voronezh state technical University \\ Voronezh, Russia \\ e-mail: bosyanyka@mail.ru
}

\begin{abstract}
The subject of this study is the organizational and economic relations arising in the process of interaction of virtual companies with the companies manufacturing technically sophisticated products. Using the research results, the mechanism of interaction of virtual companies with public and private companies on the basis of public-private partnership when creating joint ventures for the production of innovative products is substantiated. The purpose of this article is to justify the mechanism of interaction of virtual companies with public and private companies on the basis of public-private partnerships. As a result of the research, the following tasks were solved: the stages of creating a virtual company were identified, the need for specialists for the creation and functioning of virtual companies was identified, a mechanism for the interaction of a virtual company with public and private companies on the basis of public-private partnerships was formed. Interaction of virtual and public and private companies on the basis of public-private partnership was revealed, providing mutual compensation of their shortcomings and strengthening of advantages, the manifestation of the synergy effect by attracting advanced competencies of individual firms, creative teams, and individuals.
\end{abstract}

Keywords - virtual company, formation stages, state, private business, CALS-technologies, interaction mechanism, publicprivate partnership, partner relations.

\section{INTRODUCTION}

The constant change in the competitive situation on the market of technically sophisticated products leads to the emergence of new forms of their production. One of such new forms is virtual companies (VC), which get more and more developed both abroad and in Russia [1,3]. The interaction of the public and the private sector with the involvement of $\mathrm{VC}$ allows one, on the one hand, to increase the efficiency of budget financing of the companies, and on the other hand, to create favorable conditions for innovative activity for the private sector.

In fact, the state and business are becoming equal and interested partners for creation and development of innovative technologies that can ensure the competitiveness of the entire Russian economy. In this regard, the justification of the mechanism of interaction between VC and public and private companies on the basis of public-private partnership (PPP) is very relevant, especially taking into account the latest trends in the global economy.
The key objective of applying the PPP mechanism is to attract innovations, technologies, capital, and experience of private companies (organizations) in this area to increase the efficiency of use of the federal budget and companies' assets. The PPP participants are the state and entities (commercial organizations, virtual companies) of the private sector of the economy [2,5]. Therefore, it is advisable to attract VP for the production of innovative products in the framework of PPP.

On behalf of the state (public partner), the following types of organizations can play the role of participants in the PPP: state authorities; federal state companies and institutions; federal state commercial organizations (state unitary enterprises, federal treasury enterprises).

On the part of the business (private partner), partnerships may include: commercial and non-commercial organizations of various legal forms with or without state participation (joint-stock companies, virtual companies, including creative teams and individual natural persons).

Before concluding an agreement (contract) on interaction between a joint venture (JV), created by public and private partners based on PPP, and a VC, it is necessary to evaluate the possibilities of $\mathrm{VC}$ in the production of technically sophisticated products. If the characteristics of the $\mathrm{VC}$ do not meet the required ones, then it is necessary to initiate the creation of a company with the required characteristics.

$\mathrm{VC}$ is created by combining on a contractual basis companies, organizations, creative teams, and potential employees involved in the product life cycle (LC) and related to common business processes. VC, like any ordinary company, has a certain life cycle: "the emergence of a need for partnership - design - implementation - operation - termination of activity". At all stages of the life cycle of a virtual company, special methods and tools are used to improve the quality, reduce the complexity and time of the work. Therefore, the lifespan of a $\mathrm{VC}$ is determined by the duration of the project or the life cycle of its products.

\section{Methodology}

A systematic analysis of the tasks solved by the VCs, as well as the specifics of their functioning $[6,7]$, showed that the foundation of a VC is associated with the intelligent modeling of the interaction of complex, heterogeneous, distant 
companies, creative teams, and potential employees. When performing such analysis, it was found that the creation of a $\mathrm{VC}$ can be implemented in four stages. Table 1 provides a list of the key stages of the creation of the VC and a summary of the main work at each stage.

TABLE I. STAGES OF A VIRTUAL COMPANY CREATION

\begin{tabular}{|c|c|c|c|}
\hline \multicolumn{4}{|c|}{ STAGES OF A VIRTUAL COMPANY CREATION } \\
\hline Stage 1 & Stage 2 & Stage 3 & Stage 4 \\
\hline $\begin{array}{l}\text { Development of scientific ap- } \\
\text { proaches and recommendations }\end{array}$ & VC design & VC foundation & VC operation \\
\hline $\begin{array}{l}\text { 1. Development of the con- } \\
\text { cept and recommendations } \\
\text { for creation of a VC taking } \\
\text { into account the information } \\
\text { of positive experience of VC } \\
\text { operations. } \\
\text { 2. Development of the re- } \\
\text { quirements for VC foundation } \\
\text { taking into account the most } \\
\text { recent IT. } \\
\text { 3. Development of the pro- } \\
\text { cedure of VC foundation and } \\
\text { its key point testing for a cer- } \\
\text { tain research project. } \\
4 \text {. Use of the knowledge } \\
\text { and work experience in this } \\
\text { field of the actual owners of } \\
\text { the VC. }\end{array}$ & $\begin{array}{l}\text { 1. Reasoning of the idea of } \\
\text { production organization. } \\
\text { 2. Assessment of economic } \\
\text { feasibility of the project. } \\
\text { 3. Modelling of the VC op- } \\
\text { eration using software tools. } \\
\text { 4. Assessment of the tech- } \\
\text { nical feasibility of the project. } \\
\text { 5. Definition of the require- } \\
\text { ments for the automated pro- } \\
\text { cess support tools for the VC } \\
\text { foundation and operations. } \\
6 \text {. Development of the project } \\
\text { of VC foundation taking into } \\
\text { account the results of stage } 1 \text {. }\end{array}$ & $\begin{array}{l}\text { 1. Creation of the VC infra- } \\
\text { structure. } \\
\text { 2. Design of mathematical } \\
\text { models of VC participant } \\
\text { interactions. } \\
\text { 3. Creation of IT for support } \\
\text { of the VC operation processes } \\
\text { based on the use of recent } \\
\text { CALS-technologies. } \\
\text { 4. Construction of multilevel } \\
\text { user-friendly interfaces among } \\
\text { the agents. } \\
\text { 5. Prototyping and pro- } \\
\text { cessing of the business opera- } \\
\text { tion procedure within the VC } \\
\text { using BPM. }\end{array}$ & $\begin{array}{l}\text { 1. Launching the man- } \\
\text { ufacturing of technically } \\
\text { sophisticated products. } \\
\text { 2. Resource planning } \\
\text { advanced competency } \\
\text { involvement. } \\
\text { 3. Provision of opera- } \\
\text { tion of the process infra- } \\
\text { structure. } \\
\text { 4. Coordination of the } \\
\text { operations, process } \\
\text { monitoring, control of } \\
\text { the activities. } \\
5 \text {. VC termination. }\end{array}$ \\
\hline
\end{tabular}

According to Table 1, the first stage of a VC creation is "Development of scientific approaches and recommendations." At this stage the works are undertaken associated with the development of the scientific approaches to creation of such companies, all business processes are defined and estimated. Besides, the procedure is designed for $\mathrm{VC}$ foundation and its key points are tested for a certain research project.

The second stage of VC creation is "VC design", when the idea of production organization is reasoned, the assessment of economic feasibility of the project is performed. Modelling of the VC operation also takes place at this stage, goals and strategy are formulated, business process structure is defined, business process support infrastructure is formed, and the required resources are identified. Finally, the project of the VC is developed.

The third stage of VC creation is "VC foundation", which includes the works related to the organization of the VC (creation of information and process infrastructure). At this stage, a set of mathematical models for the interaction of VC participants is developed. Prototyping and development of the technology for doing business within the framework of $\mathrm{VC}$ using virtual workplaces (BPM) is performed.

The fourth stage of creating a VC is "VC operation" (see Figure 1), which includes launching the manufacturing of technically sophisticated products, planning resources, attracting advanced competencies, supporting operational activities: coordinating work, monitoring processes, activity control, as well as the termination of $\mathrm{VC}$ activities after the completion of serial production.
Knowing the stages of $\mathrm{VC}$ creation and the content of the works within each of them can facilitate the performance of the specialists in organizing multilevel user-friendly interfaces among companies, creative teams, and potential employees. In addition, the elaboration of the list of operations for the creation of VC at each stage allows one to clarify the specifics of their functioning, which will be used below to justify the mechanism of interaction of $\mathrm{VC}$ with public and private companies.

The creation of a VC as a new form of manufacturing technically sophisticated products requires the participation of a variety of specialists (Figure 1).

All the participants in the VC creation should be aimed at finding effective ways to organize it. They should be interested in the fact that new forms of production organization should be put into actual operation and their efforts should not be wasted. At the same time, the search for effective forms of combining the efforts of all participants in the $\mathrm{VC}$ is one of the main directions in the problem of $\mathrm{VC}$ creation.

\section{RESULTS AND DISCUSSION}

For $\mathrm{VC}$, the problem of information interaction and the application of CALS-technologies (Continuous Acquisitionand Lifecycle Support) is highly relevant, since they include product developers, main contractors, subcontractors, suppliers, and other executors geographically distant from each other, using heterogeneous computer platforms and software systems $[1,3]$. Building multilevel user-friendly interfaces between contractors, subcontractors, companies, creative teams, and potential employees plays a paramount role. 
Goals and tasks for creation of information and process infrastructure of a VC taking into consideration of the recent IT

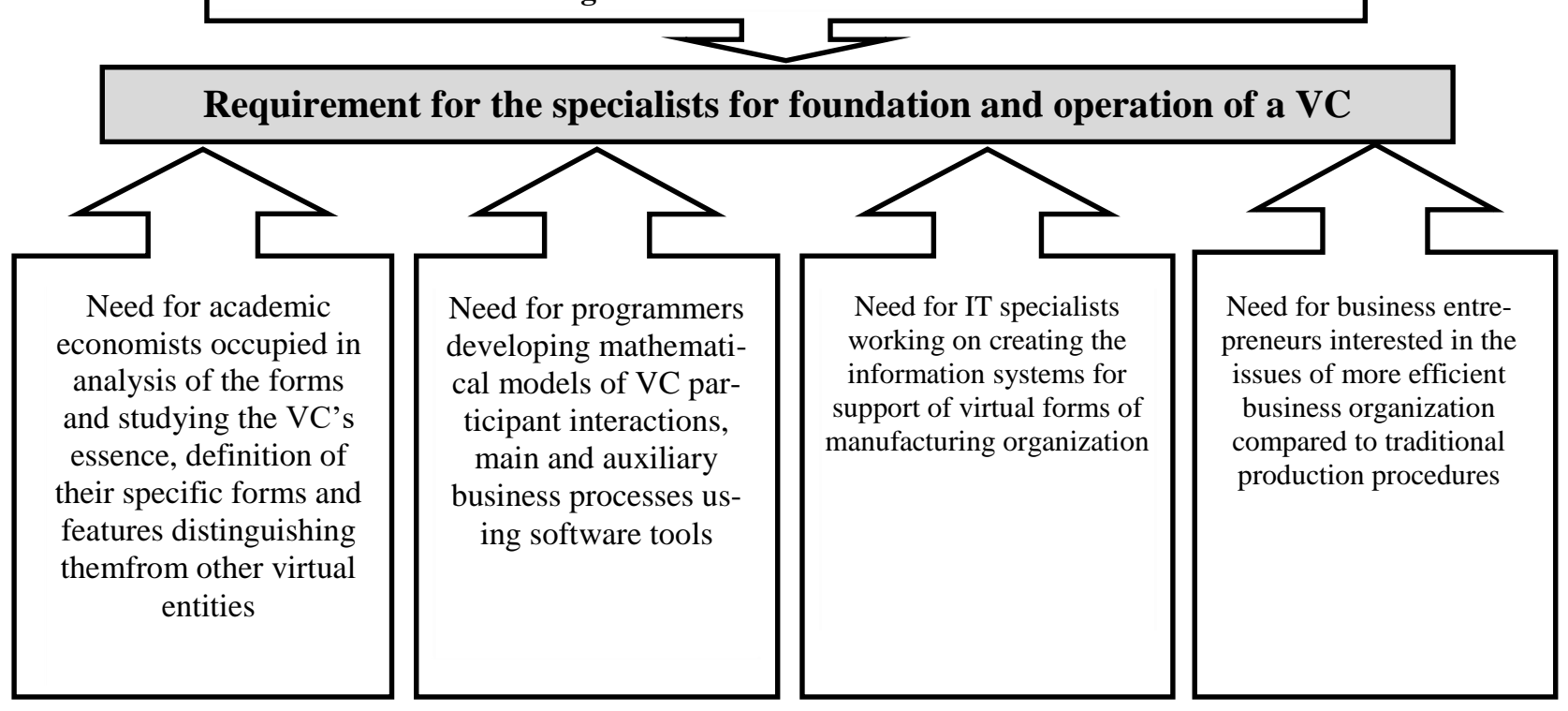

Fig. 1. Requirement for the specialists for foundation and operation of a VC

To create a VC, it is not enough just to establish a computer network and build an organization around it. First of all, it is necessary to carry out the design of a virtual space in which the company will function. This requires special people with special skills. The introduction of a fundamentally new functional organizational structure by specialists in the VC creation is an extremely difficult process, especially when it comes to the application of CALS-technologies. Ensuring the viability of the CALS structure is the most important task for the management of the private company - the coordinator of a joint project. The analysis of the specifics of the interaction of $\mathrm{VC}$ $[11,13]$ with companies of different forms of manufacturing technically sophisticated products based on the use of recent CALS-technologies made it possible to identify the typical infrastructure of such companies. Thus, two levels of CALS structures can be distinguished: the CALS center of the coordinator of a joint project (private partner) and the CALS center of a specific VC. It is impossible to get by with just single common CALS center. CALS centers of the lower level provide direct implementation of the technical policy in the VC.

The structure of the VC can include spatially distributed BPM. The interaction between BPM and VC, united on a contract basis, is carried out through the global Internet or using wireless broadband cellular technology. At the same time, BPM can be stationary or mobile, which allows one to organize BPM in any geographic region without significant financial costs. BPM includes two key components - the employee's workplace and the corporate network, which the employee uses to fulfill his functions. The employee's BPM is a computer (laptop) with installed software necessary to connect to the servers of the corporate network.

The lack of specific mechanisms for the implementation of PPP during the creation of a joint venture having contractual agreements with $\mathrm{VC}$ inhibits the interaction of the state and business. In this regard, the justification and development of the mechanism for the interaction of $\mathrm{VC}$ with public and private companies based on PPP in a market economy is required.

Figure 2 summarizes the above discussion on the creation of one of the possible options for a joint venture having contractual agreements with a VC in the form of a schematic representation of the typical mechanism for the interaction of the VC with public and private companies based on PPP. When founding a joint venture, a public partner, taking into account previously developed legislation in the field of manufacturing of innovative products based on PPP, decides what products and in what terms it should be created, sets the production volume, predicts its life cycle and establishes other requirements. The private partner and the VC form proposals which should meet the requirements as close as possible.

It is advisable to highlight a number of ideas that contribute to increasing the efficiency of the mechanism for the interaction of VCs with public and private companies on the basis of PPP. First of all, when founding a joint venture by a stateowned company (public partner), it is necessary to support and stimulate a thorough study of the proposed joint venture project. For each PPP project, it is necessary to provide detailed regulations developed by the public partner for the competition for the selection of a professional and solvent private company and innovative VC.

The mechanism of interaction of $\mathrm{VC}$ with public and private companies on the basis of PPP depicted in Figure 2 is a combination of organizational structures and specific forms, means, tools, and management methods. It also follows from the analysis of the scheme presented in this figure that PPP when creating a joint venture for the manufacturing of technically sophisticated new products should be carried out taking into account the priority actions indicated in this figure. The 
mechanism of interaction of VC with public and private companies on the basis of PPP can increase the efficiency of budget financing of Russian companies and create innovative business conditions based on joint investment of the project, both from the private and public partners. At the same time, during a period of budget deficit in the Russian Federation, such mechanism contributes to solving promising economic problems.

\section{Key actions of JV within PPP:}

Increase in efficiency of production under the integration of public, private, and virtual resources.

Development of emerging technologies for creation of new specimen products or modernization.

Broadening the participation of Russian companies in the industrial cooperation for manufacturing of high-tech products.

Contribution in forming the innovation potential due to $\mathrm{VC}$ involvement.

Development of the corporate research and non-public organizations.

Meeting the requirements of economic security of the company.

Support of the state's exclusive right for using the results of innovation activity, etc.

\section{Competitive advantages of a} VC:

High speed and flexibility in fulfilment of the market demand providing the promptness of product delivery to the market;

Possibility of full ersatz is faction of consumer's needs and reduction of the total expense at each stage of any specific project's implementation;

Manifestation of the synergy effect due to involvement of the emerging technologies of separated companies, creative teams, and natural persons;

Opportunity to choose and use the best results, staff, and abilities with lesser time and financial expenditures;

Opportunity to reduce significantly the amount of project and technological documentation in paper form, etc.

\section{State:}

Development and validation of the legal bases for the operation of public and private partner and virtual company in manufacturing of innovative products based on public-private partnership
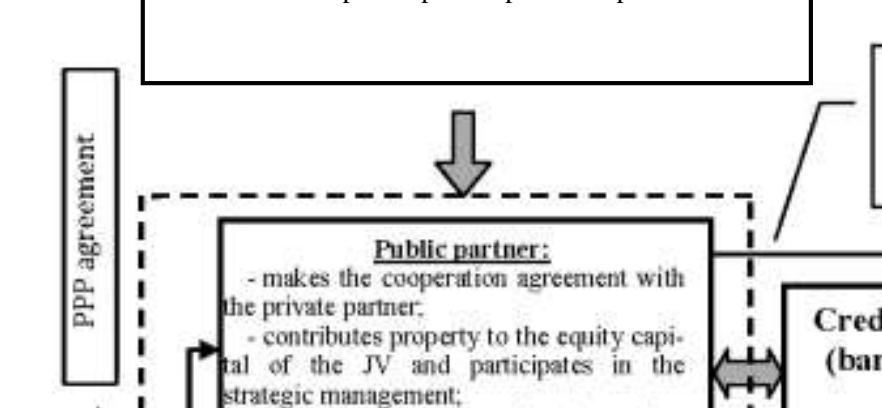

Public control and regulation - makes the coop the private partner:

- contributes property to the equity capital of the JV and participates in the trategic mantigement;

- creates CALS-center for interaction with the private partner.

- keeps the public control over all stages of oneration. etc.

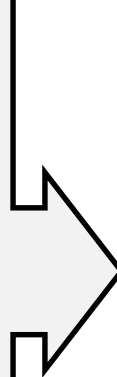

$$
\text { of }
$$

$$
\text { 1 }
$$

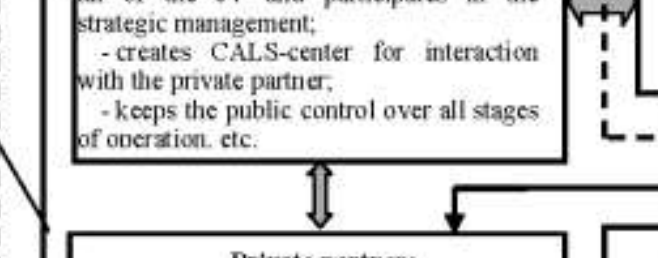

\section{Prisate partner:}

- participates in the strategic management. - designs, architects and equips the indusrial fucilities, ereates CALS-center of

1. pperation coordinator with the public partner, JV and VC,

- makes the agreement of the capacity utilization guarantees with the public partice;

-forms the in innovative pot entail through involving the VC, etc.

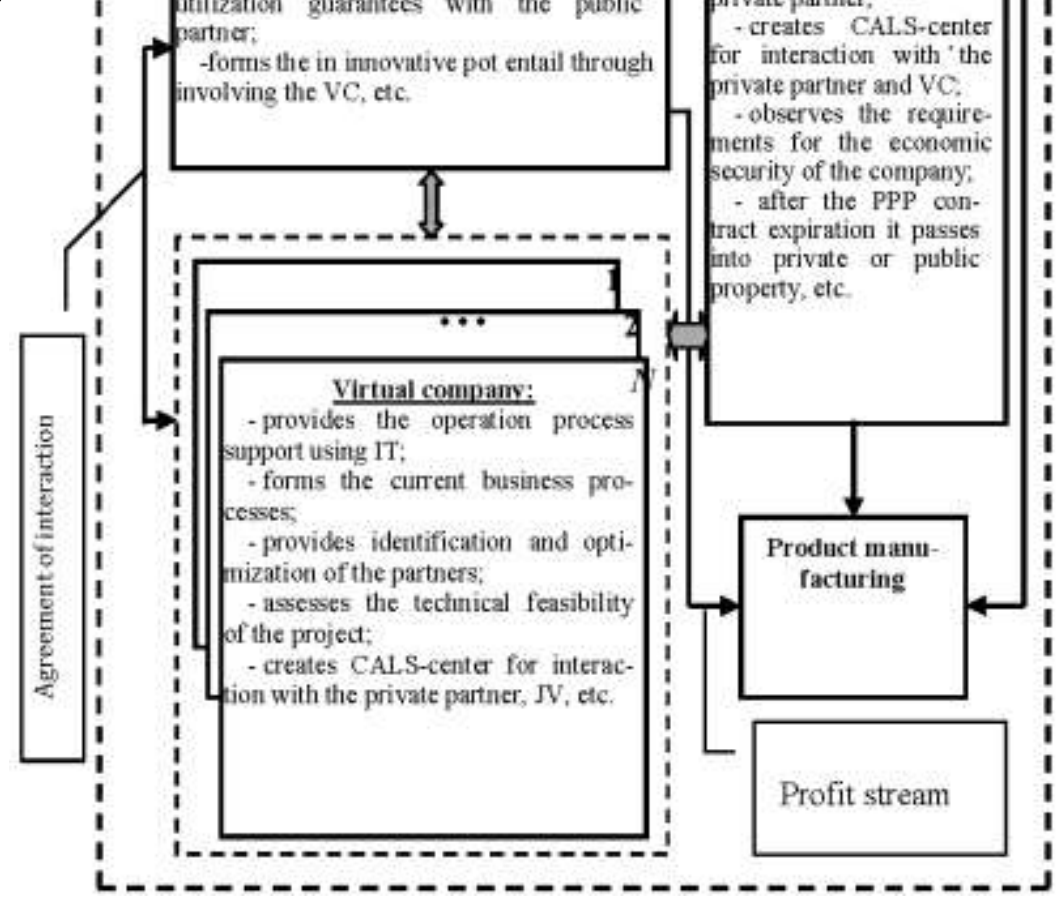

Fig. 2. The mechanism of interaction of a virtual company with public and private companies on the basis of public-private partnership 
The analysis of the specifics of interaction on a contractual basis of spatially distributed VCs and joint ventures (see Figure 2), as well as the features of interaction between public and private companies when creating a joint venture based on PPP using modern IT technologies, showed the following. When operating a joint venture in such conditions, one of the most important tasks is the task of ensuring the economic security of the company. To ensure the economic security of the joint venture, the comprehensive use of means and software tools is necessary to protect the information circulating in the local computer networks of all companies participating in the project, as well as the information transmitted via wireless data transmission channels between the VC, public partner and the joint venture, and their structural units. The security of a joint venture can be ensured using IT technology by achieving the following main tasks $[4,5]$ :

(i) planning and working out the strategies and solutions for company's economic security provision;

(ii) timely detection of external organizational and process measures and internal threats for vital interests of the company from the part of criminal elements, unscrupulous competitors, and other individuals, as well as crisis events in the economy, managerial incompetence, social strain;

(iii) definition of qualitative and quantitative values of financial security indicators, potential risks and threats in the information space;

(iv) elimination of access to information constituting a trade secret for any persons without the consent of its owner;

(v) timely detection and prevention of information leak through the technical channels with the help of information technologies;

(vi) ensuring protection of the information circulating in computer facilities and wireless networks against unauthorized access;

(vii) elimination of intentional software and mathematical effects on information;

(viii) elimination of destructive influence on the information system of the company from a male factor as a result of occurrence of some or other threat to the information security;

(ix) maintaining order and suitable regime of closure within the company, elimination of careless handling of official documents;

(x) ensuring a clear functioning system of incentives for employees of the company for making effective managerial decisions and a system of sanctions for the negative consequences of their actions in the field of economic security;

(xi) provision of physical security for the management and employees of the company by organizing a system of preventive measures, as well as due to the professionalism of the guards and the discipline of the protected person;

(xii) prevention of the penetration (both intelligence and technical) to access the confidential information (commercial secret) of the company and ensuring the safety of the company's information resources.

\section{CONCLUSION}

The production activity of the joint venture obliges its management, in cooperation with the public partner, to create a special structure to ensure the economic security of the company. It should analyze external and internal threats to the economic security of the company, study financial information, calculate and analyze indicators of financial security. This structure should ensure the development of organizational and technical measures to protect information, as well as the acquisition and operation of technical means of information protection.

The interaction of the VC with public and private companies on the basis of PPP provides mutual compensation of their shortcomings and enhances their benefits, the manifestation of the synergy effect by attracting advanced competencies of individual companies, creative teams, and individuals. There is a possibility of combining the advantages of the public partner with strong stability and inertia, and the advantages of promising private and virtual companies that can adapt speedily. There is an artificial (virtual) community in the form of a joint venture formed using IT, which very often extends the life cycle of virtual companies. At the same time, VC is a network structure that is fully customer-oriented, since its main characteristics are speed of order execution and prompt delivery of manufactured components and products to the market.

Thus, the interaction of the state and business on the basis of PPP using virtual companies is one of the most important conditions for increasing the innovative activity of industrial companies, improving the existing one and creating a promising economic infrastructure in Russia. Implementation of the developed mechanism for the interaction of virtual companies with public and private companies based on PPP will ensure the updating of the plans for the implementation of new innovative projects and increase the effectiveness of budget financing.

\section{References}

[1] D.A. Shageev, T.A. Chuhonceva, "Universal rapid method of assessment and management decision-making of situational problems in the enterprise", Proc. of Voronezh State Univer. of Engineer. Technol., vol. 81, no. 2, pp. 359-376, 2019, Retrieved from: https://doi.org/10.20914/2310-1202-2019-2-359-376

[2] Y.P. Anisimov, Y.V. Zhuravlev, I.V. Kuksova, E.I. Balabanova, A.Y. Zhilnikov, T.V. Elagina, "Spatial analysis of the development ofinnovative potential of enterprises", Proc. of Voronezh State Univer. of Engineer. Technol., vol. 81, no. 1, pp. 391-396, 2019, Retrieved from: https://doi.org/10.20914/2310-1202-2019-1-391-396

[3] I.V. Kazmina, E.A. Titova, "Mechanism of implementation of publicprivate partnership at the enterprises of the military-industrial complex", Proc. of Voronezh State Univer. of Engineer. Technol., vol. 81, no. 1, pp. 412-419, 2019, Retrieved from: https://doi.org/10.20914/2310-12022019-1-412-419

[4] N.S. Serebryakova, A.V. Petrikov, "The principles of design and the organization of functioning of innovative infrastructures in the conditions of the Industry 4.0", Proc. of the Voronezh State Univer. of Engineer. Technol., vol. 80, no. 4, pp. 384-387, 2018, Retrieved from: https://doi.org/10.20914/2310-1202-2018-4-384-387

[5] O.O. Lukina, V.V. Dudchak, "Generalized indicator and classification structures of the capital of the industrial enterprises", Proc. of the Voronezh State Univer. of Engineer. Technol., vol. 80, no. 3, pp. 423-428, 
2018, Retrieved from: https://doi.org/10.20914/2310-1202-2018-3-423428

[6] E. Shkarupeta, I. Karapetyants, Y. Kostuhin, T. Tolstykh, "Transformation of logistical processes in digital economy”, pp. 838-844, 2017 [Proc. of the 30th Int. Business Information Management Association Conf. (IBIMA)], Spain

[7] E. Shkarupeta, T. Tolstykh, Y. Kostuhin, A. Zhaglovskaya, "Digital Innovative Manufacturing basing on Formation of an Ecosystem of Services and Resources", pp. 4738-4746, 2018 [Proc. of the 31th Int. Business Information Management Association Conf. (IBIMA)], Italy.

[8] V.D. Sekerin, V.V. Burlakov, O.A. Dzurdzya, A.E. Gorohova, "Peculiarities of Forecasting Competitiveness of Innovations for Industrial Enterprises", Int. J. of Econ. and Financial Issuesv., vol. 5, no. 35, pp. 54-60, 2015.

[9] V.D. Sekerin, V.V. Burlakov, V.S. Bank, A.E. Gorokhova, "Latency of innovations as economic category of innovative process", Revista Espacios, vol. 38, no. 33, p. 22, 2017.

[10] M.A. Kravets, "Algorithm and methodology of diagnostics of communication system of the enterprise", MATEC Web Conf., 4-7 July 2018 [Int. Geotechnical Symp. Geotechnical Construction of Civil Engineering \& Transport Structures of the Asian-Pacific Region, p. 265, 2019, Yuzhno-Sakhalinsk], Retrieved from: https://www.matecconferences.org/articles/matecconf/pdf/2019/14/mate cconf_gccets2018_07030.pdf

[11] M.V. Mikhaylyuk, V. Baginova, E.A. Mamaev, "Empirical markers in the concept of digital logistics of multichannel supply chains", Topical
Problems of Architecture, Civil Engineering and Environmental Economics (TPACEE 2018), vol. 91, 2019 [E3S Web of Conf.], Retrieved from: https://www.e3s-conferences.org/articles/ e3sconf/pdf/2019/17/e3sconf_tpacee2019_08056.pdf

[12] E.V. Limonova, I.V. Manakhova, Socioeconomic Leadershipof the Individual in the Information Economy: Nanolevel of Research, Leadership for the Future Sustainable, Development of Business and Education, Springer Proceedings in Business and Economics, Springer, Cham 2018, pp. 551-558.

[13] A.G. Nazarov, A.A. Galushrin, E.N. Sabyna, T.V. Skryl, "The institutional model of formation and development of industry 4.0 in the conditions of knowledge economy's formation", Industry 4.0: Industrial Revolution of the 21 st Century [Studies in Systems, Decision and Control], Springer, 2019, pp. 219-226.

[14] M. Chuvashlova, V. Nikolaev, "Efficiency of Managerial Control Systems: The optimal Model”, Europ. Res. Studies J., vol. XXI, iss. 3, pp. 675-689, 2018.

[15] A. Habibipour, A. Padyab, B. Bergvall-Kåreborn, A. Ståhlbröst, "Exploring Factors Influencing Participant Drop-Out Behavior in a Living Lab Environment", Nordic Contributions in IS Research. SCIS 2017. Lecture Notes in Business Information Processing, vol. 294, 2017, Springer, Cham. Retrieved from: https://doi.org/10.1007/978-3-31964695-4_3

[16] B. Ley, C. Ogonowski, M. Mu, J. Hess, N. Race, D. Randall, M. Rouncefield, V. Wulf, "At home with users: a comparative view of living labs", Interact. Comput., no. 27, pp. 21-35, 2015. 